\title{
Ergonomic risk factors and Work-related Musculoskeletal Disorders among Fireworks workers in West Bengal, India: A cross-sectional study
}

${ }^{1}$ Payel Laskar, *2Subhadeep Ganguly and *12 Zakir Md Hossain

1. Department of Biological Sciences, Aliah University, Action area IIA/27, New Town, Kolkata-700160, West Bengal, India

2. Department of Physiology, Vidyasagar College, 39 Sankar Ghosh Lane, Kolkata-700006, West Bengal, India

*Address for correspondence: zakirmd@aliah.ac.in / res_biol@ rediffmail.com

\begin{abstract}
Fireworks industries are very old, unorganized cottage industries in West Bengal mainly confined in South 24 Parganas. The present investigation was intended to investigate the prevalence of work-related musculoskeletal disorders among the workers and to identify the causative factors behind it. In this present study, 152 male fireworks workers from different age groups and 100 control subjects were investigated. Modified Nordic questionnaires were used to identify the region-wise disorders. The Hand Grip strength of both groups was also estimated. Among the fireworks workers posture related musculoskeletal disorders were severely observed in the lower back which was aggravated with the advancement of age and working experience. Pain and stiffness were also reported in the neck, upper back, wrist, elbow, knee and ankle. A lower backrest with support at the lumber region is strongly recommended.
\end{abstract}

[Key words: Fireworks, cottage, prevalence, musculoskeletal, Nordic]

\section{Introduction}

Fireworks industries are well-known ancient but hazardous cottage industries in India. Fireworks mainly emit light, sound, gas and heat on ignition of pyrotechnic chemical ${ }^{1}$. It creates extensive environmental pollution within a short time, deposits metal dust, toxins and other harmful chemicals. Workers continuously exposing its manufacture also affected adversely. In West Bengal, the largest fireworks hub is situated in Champahati, South 24 Parganas which includes around 19 villages across four-gram panchayats. Approximately 5000 workers are involved in this profession which involves 800 trades directly with an estimated revenue collection of around 25 crores per annum (A report published on The Times of India, October'26, 2019).

Disabilities associated with Works related musculoskeletal disorders (WMSDs) are very common but rapidly increasing socio-economic problems in industrial sectors ${ }^{2-6}$. Risk factors that aggravate the situation include posture, repetition, material handling, mechanical compression, force,

temperature, extremities, vibration, glare, duration of exposure, inadequate lighting, etc ${ }^{7-15}$. But very few reports are available on the health hazards associated with the fireworks workers. Like 
other industrial workers, WMSDs are very common among fireworks workers. Musculoskeletal disorders are commonly referred to as injuries and disorders to the muscles, tendons, joints, ligaments, cartilage, nerves or spinal disc ${ }^{16}$. Postural discomforts are associated with works related musculoskeletal disorders mainly in the lower back, shoulder, upper extremities among the workers. So far as the information is available, probably it is the first report of works related to musculoskeletal disorders among fireworks workers in the state of West Bengal.

The present work was aimed to assess the ergonomic risk factors associated with the development of WMSDs among male fireworks workers in West Bengal, India.

\section{Materials and methods}

\section{Inclusion and exclusion criteria:}

Inclusion criteria include: (i) age of the workers > 18years, (ii) female workers and physically disable male workers were excluded from the present study. In this way, 73 workers in 17 factories were excluded.

\section{Selection of Subjects:}

There are 152 male fireworks workers were selected for the experimental group. 100 workers who are not attached to the field of fireworks and not involved in awkward postures like fireworks workers were selected for the control group. The control group was divided into four subgroups according to their age (A: 20-29years, B: 30-39years, C: 40-49years, D: above 50 years); and were physically and mentally healthy. They work in different fields other than fireworks. The experimental group was also similarly divided into four subgroups according to their age (A: 2029years, B: 30-39years, C: 40-49years, D: above 50 years).

\section{Physical Parameters:}

The height and weight of the fireworks workers and the control group were measured with a Martin anthropometer (Takei, Japan) and a Crown weighing machine (Raymon Surgical, India) respectively. The body surface area $(\mathrm{BSA})^{17}$ and the body mass index $(\mathrm{BMI})^{18}$ of all the subjects were also computed.

\section{Questionnaire:}

A standardized Nordic questionnaire was used for this study ${ }^{19}$. The questionnaire was represented in the form of multiple choice. The subjects were informed about the objective of the study and all had their consent. The questions are divided into two groups based on general information of workers and pain of discomfort body parts.

\section{Study Period \& Working Area:}

The study was conducted from April 2018 to March 2020. The workplace is in west Bengal, India. 


\section{Working Environment:}

The wet bulb globe temperature (WBGT) of the workplace of fireworks workers was calculated ${ }^{20}$. Mean globe temperature, wet and dry bulb temperatures were recorded.

The formula of the WBGT is equal to $-0.7 \bullet \mathrm{NWB}+0.3 \bullet \mathrm{GT}$, $(\mathrm{NWB}=$ Natural wet bulb and GT $=$ Globe temperature $)$

Relative humidity was also estimated from the psychometric chart which was developed by Weksler Instrument (USA) ${ }^{21}$.

\section{Statistical Analysis:}

Student's t-test was used between the two groups of workers to find out whether there was any significant difference between the pain of discomfort part of the experimental and the control groups.

\section{Analysis of Working Posture:}

To analyze the working posture, Rapid Entire Body Assessment (REBA) ${ }^{22}$, proposed by Hignett and McAtamney was used. And to assess the risk of work-related musculoskeletal disorders (WRMSDs), Rapid upper limb assessment (RULA) ${ }^{23}$ was used.

\section{Discomfort Level Scale:}

To identify the discomfort level score, a ten-point scale was used ${ }^{24} .0$ represented 'no discomfort' and 10 represented 'worst discomfort (extremely uncomfortable)'. This scale was used to identify the discomfort level of the fireworks workers in their different postures. The intensity of pain or discomfort was measured by utilizing the body part discomfort (BPD) scale.

\section{Risk level scale:}

A ten-point scale was also used for assessment of the level of risk in working posture, where 1 meant 'no risk or negligible' whereas 10 meant 'very high risk'. After performing REBA and RULA methods on different postures of the workers, the result of the posture analysis was compared with the scale.

\section{Results}

The overall demographic data of Fireworks workers and the control group are presented in Table 1. Between these two groups, height, weight, BSA, BMI and year of experience vary significantly. Mean age does not show any significant difference. Duration of work per day, duration of rest per day and number of working days per week are the same for these two groups. The overall steps involved in fireworks are presented in a flow chart (Fig 1). 


\begin{tabular}{|l|c|c|c|}
\hline \multicolumn{1}{|c|}{ Table 1. Demographic data of Fireworks workers and Control group } \\
\hline Variable & $\begin{array}{c}\text { Fireworks workers } \\
(\text { Mean } \pm \text { SD) }\end{array}$ & $\begin{array}{c}\text { Control group } \\
(\text { Mean } \pm \text { SD) }\end{array}$ & Remarks \\
\hline Age (year) & $38.32 \pm 10.96$ & $36.14 \pm 11.05$ & Not significant $(p=0.1249)$ \\
\hline Height $(\mathrm{cm})$ & $166.11 \pm 9.45$ & $168.69 \pm 6.35$ & Significant $(p=0.0173)$ \\
\hline Weight $(\mathrm{Kg})$ & $57.19 \pm 8.56$ & $62.39 \pm 10.29$ & Significant $(p<0.0001)$ \\
\hline BSA $\left(\mathrm{m}^{2}\right)$ & $1.63 \pm 0.15$ & $1.70 \pm 0.15$ & Significant $(p=0.0004)$ \\
\hline BMI $\left(\mathrm{Kg} / \mathrm{m}^{2}\right)$ & $20.73 \pm 2.75$ & $21.87 \pm 2.96$ & Significant $(p=0.0020)$ \\
\hline Year of experience & $17.3 \pm 2.17$ & $14.8 \pm 1.68$ & Significant $(p<0.0001)$ \\
\hline $\begin{array}{l}\text { Duration of work } \\
\text { per day (Hours) }\end{array}$ & 8.0 & 8.0 & - \\
\hline $\begin{array}{l}\text { Duration of rest per } \\
\text { day (Hour) }\end{array}$ & 1.0 & 1.0 & - \\
\hline $\begin{array}{l}\text { No. of working } \\
\text { days per week }\end{array}$ & 06 & 06 & - \\
\hline \multicolumn{4}{|c|}{ Mean values were presented. Within the parentheses, SD values were given. } \\
\hline
\end{tabular}

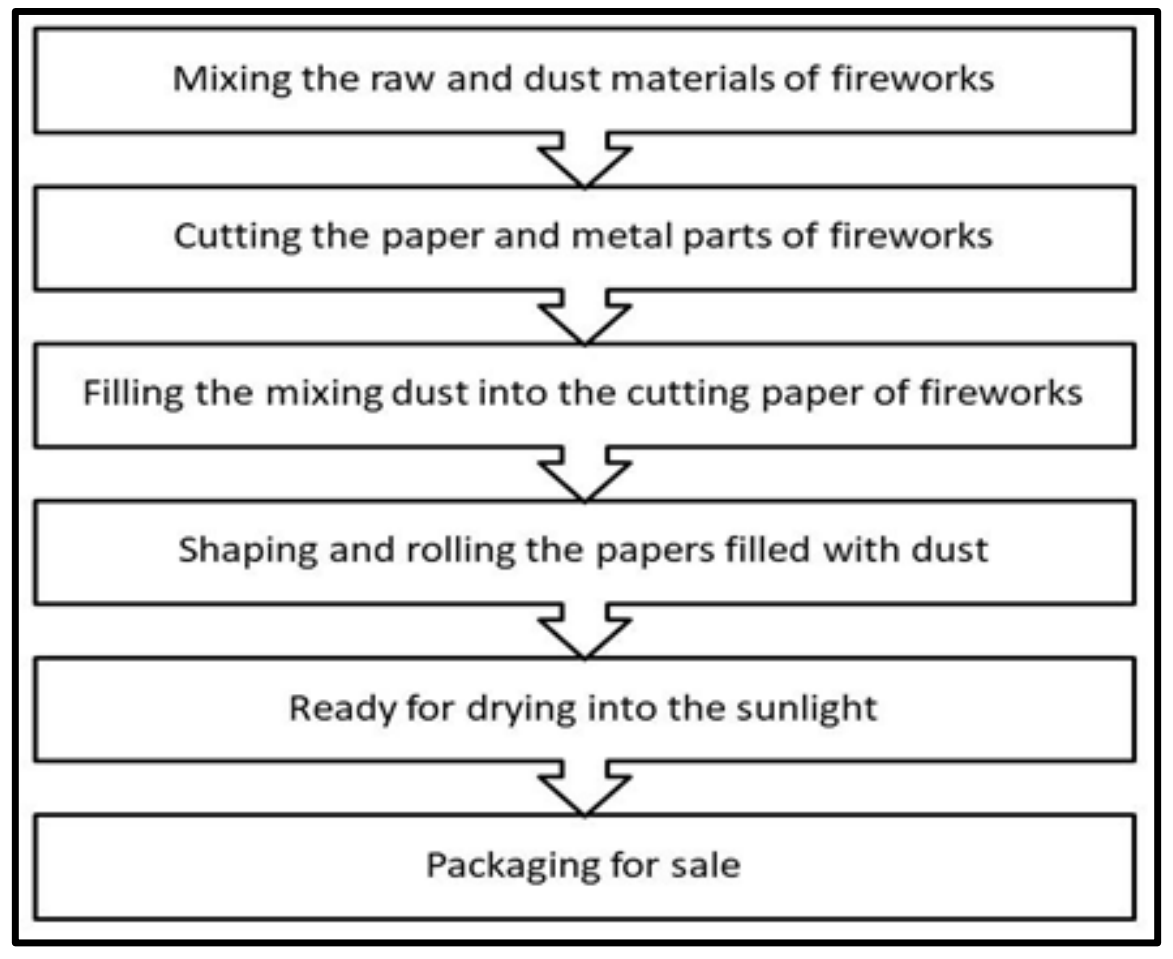

Fig 1. Flow chart of Fireworks process

The modified Nordic musculoskeletal questionnaire analysis revealed that discomfort in different body parts among Fireworks workers are predominantly reported in the knee, lower back, and upper back regions. Discomforts in the neck, shoulder, elbow and wrist are also found (Table 2). Types of injury in different body parts associated with fireworks are presented in Table 3. 


\begin{tabular}{|c|c|c|c|}
\hline \multicolumn{4}{|c|}{$\begin{array}{c}\text { Table 2: Comparison of discomfort in different body parts between Fireworks } \\
\text { workers and control group }\end{array}$} \\
\hline \multirow[b]{2}{*}{ Age groups } & \multirow{2}{*}{ Body parts involved } & Fireworks workers & Control group \\
\hline & & $\mathrm{N}=32$ & $\mathrm{~N}=28$ \\
\hline $20-29$ & $\begin{array}{l}\text { Neck } \\
\text { Shoulder } \\
\text { Elbow } \\
\text { Wrist } \\
\text { Upper back } \\
\text { Lower back } \\
\text { Hip } \\
\text { Knee } \\
\text { Ankle } \\
\end{array}$ & $\begin{array}{c}8(25.0 \%) \\
4(12.5 \%) \\
4(12.5 \%) \\
4(12.5 \%) \\
3(9.37 \%) \\
4(12.5 \%) \\
- \\
- \\
-\end{array}$ & $\begin{array}{c}5(17.85 \%) \\
- \\
- \\
- \\
- \\
- \\
- \\
- \\
- \\
\end{array}$ \\
\hline \multirow[b]{2}{*}{$30-39$} & \multirow[b]{2}{*}{$\begin{array}{l}\text { Neck } \\
\text { Shoulder } \\
\text { Elbow } \\
\text { Wrist } \\
\text { Upper back } \\
\text { Lower back } \\
\text { Hip } \\
\text { Knee } \\
\text { Ankle }\end{array}$} & $\mathrm{N}=54$ & $\mathrm{~N}=49$ \\
\hline & & $\begin{array}{c}15(27.77 \%) \\
17(31.48 \%) \\
12(22.22 \%) \\
12(22.22 \%) \\
26(48.14 \%) \\
29(53.70 \%) \\
- \\
2(3.70 \%) \\
1(1.85 \%)\end{array}$ & $\begin{array}{c}- \\
- \\
7(14.28 \%) \\
- \\
17(34.69 \%) \\
19(38.77 \%) \\
- \\
- \\
-\end{array}$ \\
\hline \multirow[b]{2}{*}{$40-49$} & \multirow[b]{2}{*}{$\begin{array}{l}\text { Neck } \\
\text { Shoulder } \\
\text { Elbow } \\
\text { Wrist } \\
\text { Upper back } \\
\text { Lower back } \\
\text { Hip } \\
\text { Knee } \\
\text { Ankle }\end{array}$} & $\mathrm{N}=46$ & $\mathrm{~N}=15$ \\
\hline & & $\begin{array}{c}11(23.91 \%) \\
10(21.73 \%) \\
8(17.39 \%) \\
9(19.56 \%) \\
31(67.39 \%) \\
33(71.73 \%) \\
- \\
13(28.26 \%) \\
6(13.04 \%)\end{array}$ & $\begin{array}{c}2(13.33 \%) \\
8(16.32 \%) \\
- \\
- \\
4(26.66 \%) \\
6(40.00 \%) \\
- \\
3(20.00 \%) \\
-\end{array}$ \\
\hline \multirow[b]{2}{*}{50 and above } & \multirow[b]{2}{*}{$\begin{array}{l}\text { Neck } \\
\text { Shoulder } \\
\text { Elbow } \\
\text { Wrist } \\
\text { Upper back } \\
\text { Lower back } \\
\text { Hip } \\
\text { Knee } \\
\text { Ankle }\end{array}$} & $\mathrm{N}=20$ & $\mathrm{~N}=8$ \\
\hline & & $\begin{array}{c}3(15 \%) \\
3(15 \%) \\
3(15 \%) \\
4(20 \%) \\
7(35 \%) \\
10(50 \%) \\
- \\
14(70 \%) \\
4(20 \%)\end{array}$ & $\begin{array}{c}- \\
1(6.66 \%) \\
- \\
- \\
6(75.00 \%) \\
7(87.50 \%) \\
- \\
7(87.50 \%) \\
-\end{array}$ \\
\hline
\end{tabular}


Table 3. Types of injury between Fireworks workers and control group

\begin{tabular}{|c|c|c|c|c|}
\hline Type of injury & \multicolumn{2}{|c|}{ Body parts } & Fireworks workers & Control group \\
\hline \multirow{6}{*}{ PAIN } & \multirow{3}{*}{ 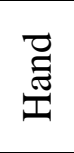 } & Elbow & 17.76 & 7 \\
\hline & & Wrist & 19.08 & 0 \\
\hline & & Finger & 19.73 & 9 \\
\hline & \multirow{3}{*}{$\stackrel{\infty}{9}$} & Knee & 19.79 & 10 \\
\hline & & Ankle & 7.24 & 0 \\
\hline & & Feet & 11.18 & 5 \\
\hline \multirow{6}{*}{ TINGLING } & \multirow{3}{*}{ 焉 } & Elbow & 1.31 & 0 \\
\hline & & Wrist & 3.04 & 0 \\
\hline & & Finger & 3.04 & 0 \\
\hline & \multirow{3}{*}{$\stackrel{\infty}{\underbrace{\infty}}$} & Knee & 1.31 & 0 \\
\hline & & Ankle & 0.66 & 0 \\
\hline & & Feet & 0.66 & 0 \\
\hline \multirow{6}{*}{ SPRAIN } & \multirow{3}{*}{$\begin{array}{l}\overrightarrow{\widetilde{E}} \\
\text { I }\end{array}$} & Elbow & 5.26 & 0 \\
\hline & & Wrist & 11.84 & 0 \\
\hline & & Finger & 16.44 & 0 \\
\hline & \multirow{3}{*}{ త్ర } & Knee & 0.66 & 0 \\
\hline & & Ankle & 14.47 & 3 \\
\hline & & Feet & 13.16 & 0 \\
\hline \multirow{6}{*}{ ABRASION } & \multirow{3}{*}{$\begin{array}{l}\widetilde{\Xi} \\
\text { ज్ }\end{array}$} & Elbow & 3.29 & 0 \\
\hline & & Wrist & 16.45 & 1 \\
\hline & & Finger & 16.45 & 1 \\
\hline & \multirow{3}{*}{ 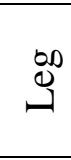 } & Knee & 1.32 & 0 \\
\hline & & Ankle & 4.60 & 0 \\
\hline & & Feet & 5.26 & 0 \\
\hline \multirow{6}{*}{ NUMBNESS } & \multirow{3}{*}{ 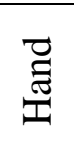 } & Elbow & 4.60 & 0 \\
\hline & & Wrist & 5.92 & 0 \\
\hline & & Finger & 6.58 & 0 \\
\hline & \multirow{3}{*}{$\stackrel{60}{9}$} & Knee & 4.60 & 0 \\
\hline & & Ankle & 3.29 & 0 \\
\hline & & Feet & 2.63 & 0 \\
\hline \multirow{6}{*}{ SWELLING } & \multirow{3}{*}{$\begin{array}{l}\widetilde{\Xi} \\
\text { I }\end{array}$} & Elbow & 1.32 & 0 \\
\hline & & Wrist & 7.9 & 2 \\
\hline & & Finger & 8.6 & 3 \\
\hline & \multirow{3}{*}{$\underbrace{\infty}$} & Knee & 1.97 & 0 \\
\hline & & Ankle & 1.32 & 0 \\
\hline & & Feet & 6.6 & 4 \\
\hline \multirow{3}{*}{ LACERATION } & \multirow{3}{*}{$\begin{array}{l}\text { I } \\
\text { I }\end{array}$} & Elbow & 3.29 & 0 \\
\hline & & Wrist & 7.89 & 0 \\
\hline & & Finger & 10.53 & 2 \\
\hline
\end{tabular}




\begin{tabular}{|c|c|c|c|c|}
\hline & \multirow{3}{*}{ త్ర } & Knee & 1.97 & 0 \\
\hline & & Ankle & 2.63 & 0 \\
\hline & & Feet & 11.84 & 1 \\
\hline
\end{tabular}

Table 4 represents handgrip strength between fireworks workers and control group at different positions of elbow as well as at rest. In all cases, fireworks workers show significant differences with the control group.

\begin{tabular}{|c|c|c|c|}
\hline \multicolumn{3}{|c|}{ Table 4. Comparison of Hand Grip Strength between Fireworks workers and Control } \\
group \\
\hline Hand posture & Fireworks workers & Control group & Remarks \\
\hline $\begin{array}{c}\text { Elbow flexion } \\
\left(90^{0}\right)\end{array}$ & $44.41 \pm 2.11$ & $41.32 \pm 1.64$ & Significant $(p<0.0001)$ \\
\hline $\begin{array}{c}\text { Post work } \\
\text { resting }\end{array}$ & $40.31 \pm 2.01$ & $38.17 \pm 1.41$ & Significant $(p<0.0001)$ \\
\hline $\begin{array}{c}\text { Elbow extension } \\
\left(180^{0}\right)\end{array}$ & $41.32 \pm 1.66$ & $40.41 \pm 2.16$ & Significant $(p<0.0002)$ \\
\hline $\begin{array}{c}\text { Post work } \\
\text { resting }\end{array}$ & $38.47 \pm 2.16$ & $37.11 \pm 1.41$ & Significant $(p<0.0002)$ \\
\hline \multicolumn{3}{|c|}{ Values were expressed as Mean \pm SD } \\
\hline
\end{tabular}

Rapid Entire Body Assessment (REBA) and Rapid Upper Limb Assessment (RULA) at different body postures among the fireworks workers are resented with discomfort levels in terms of 10point scale score in Table 5.

\begin{tabular}{|l|c|c|c|c|c|c|}
\hline \multicolumn{6}{|c|}{ Table 5. Analysis of working posture of Fireworks workers by REBA and RULA } \\
\hline \multicolumn{1}{|c|}{$\begin{array}{c}\text { Activity } \\
\text { Figure }\end{array}$} & Figure & $\begin{array}{c}\text { REBA } \\
\text { Score }\end{array}$ & $\begin{array}{c}\text { RULA } \\
\text { Score }\end{array}$ & $\begin{array}{c}\text { Risk } \\
\text { Level }\end{array}$ & $\begin{array}{c}\text { Action } \\
\text { Category }\end{array}$ & $\begin{array}{c}10 \text { Point } \\
\text { scale score }\end{array}$ \\
\hline $\begin{array}{l}\text { 1. Mixing the } \\
\text { dusts of } \\
\text { fireworks }\end{array}$ & & 8 & 7 & high & $\begin{array}{c}\text { Necessary } \\
\text { soon }\end{array}$ & 8 \\
\hline $\begin{array}{l}\text { 2. Cutting the } \\
\text { metal part of } \\
\text { fireworks }\end{array}$ & & 7 & 5 & medium & necessary & 7 \\
\end{tabular}




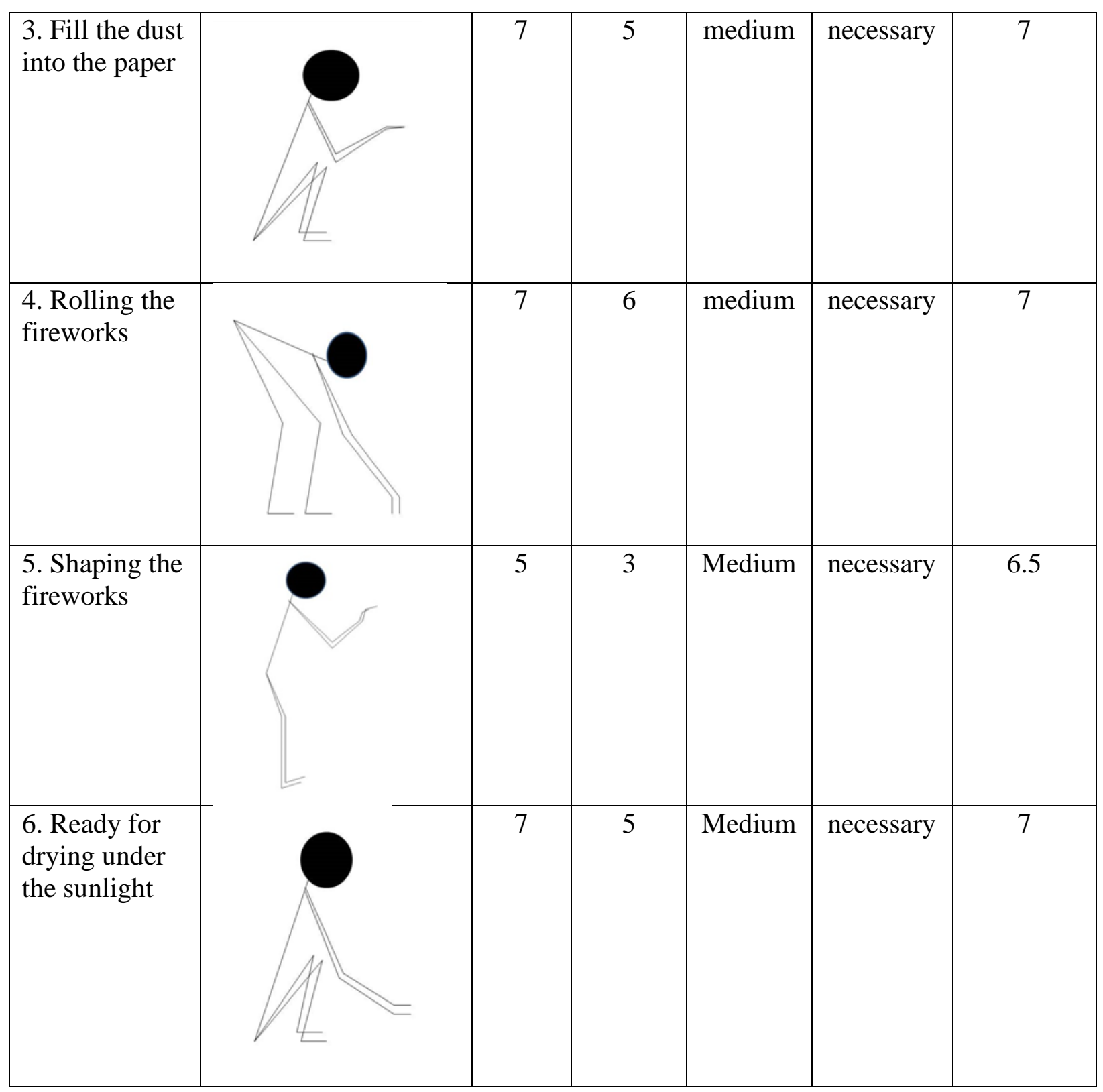

Fig 2 shows linear regression between discomfort levels and risk levels at different working postures in entire body parts. Table 6 presents lower body parts show significant $(\mathrm{p}<0.05)$ positive correlation $(\mathrm{r}=0.862)$ with discomfort level. 


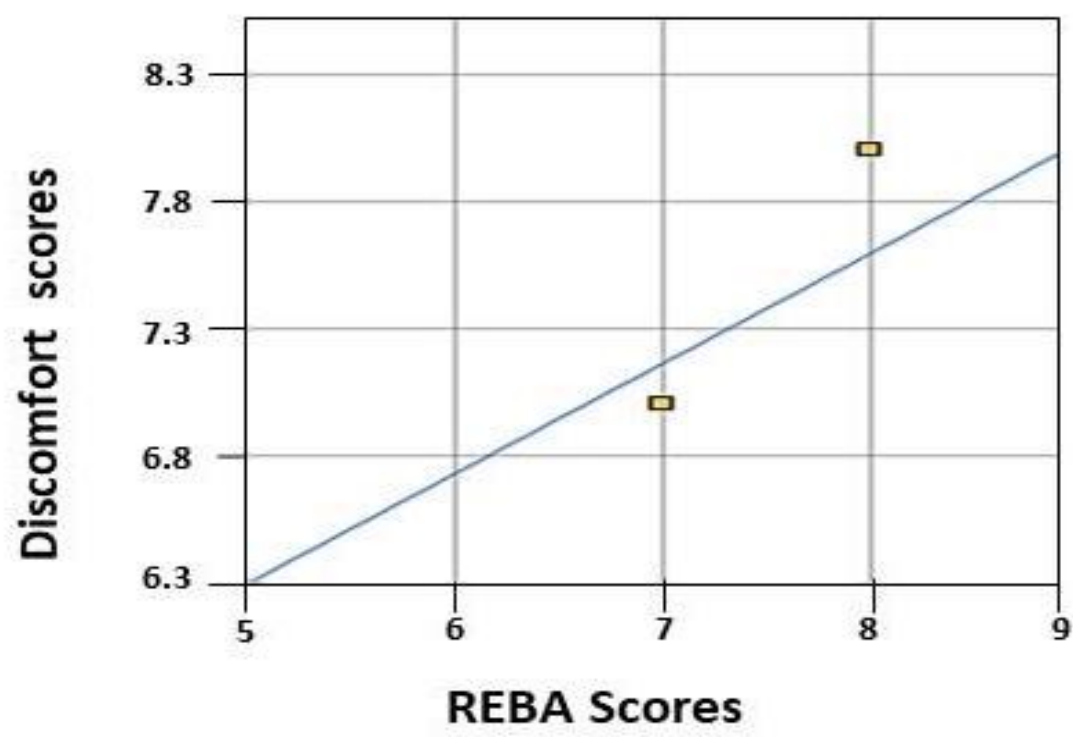

Regression line $-\hat{\mathrm{y}}=0.43103 X+4.13793$

Fig 2. Linear regression between discomfort level and risk level at entire body parts in different working posture

\begin{tabular}{|c|c|c|}
\hline \multicolumn{3}{|c|}{ Table 6. Correlation between entire body parts and discomfort levels } \\
\hline Figures (from Table 3) & REBA score & $\begin{array}{c}\text { Level of discomfort (from 10 } \\
\text { point scale) }\end{array}$ \\
\hline 1 & 8.0 & 8.0 \\
\hline 2 & 7.0 & 7.0 \\
\hline 3 & 7.0 & 7.0 \\
\hline 4 & 7.0 & 7.0 \\
\hline 5 & 5.0 & 6.5 \\
\hline 6 & 7.0 & 7.0 \\
\hline $\begin{array}{l}\text { Pearson's correlation } \\
\text { coefficient (r) }\end{array}$ & 0.862 (strong positive correlation) \\
\hline$p$-value & \multicolumn{2}{|c|}{0.272} \\
\hline \multicolumn{2}{|c|}{ The result is significant at $p<0.05$ level } \\
\hline
\end{tabular}

Fig 3 presents linear regression between discomfort levels and risk levels in upper limbs. Table 7 shows a significant $(p<0.05)$ positive correlation $(p=0.016)$ between REBA scores and discomfort levels. 


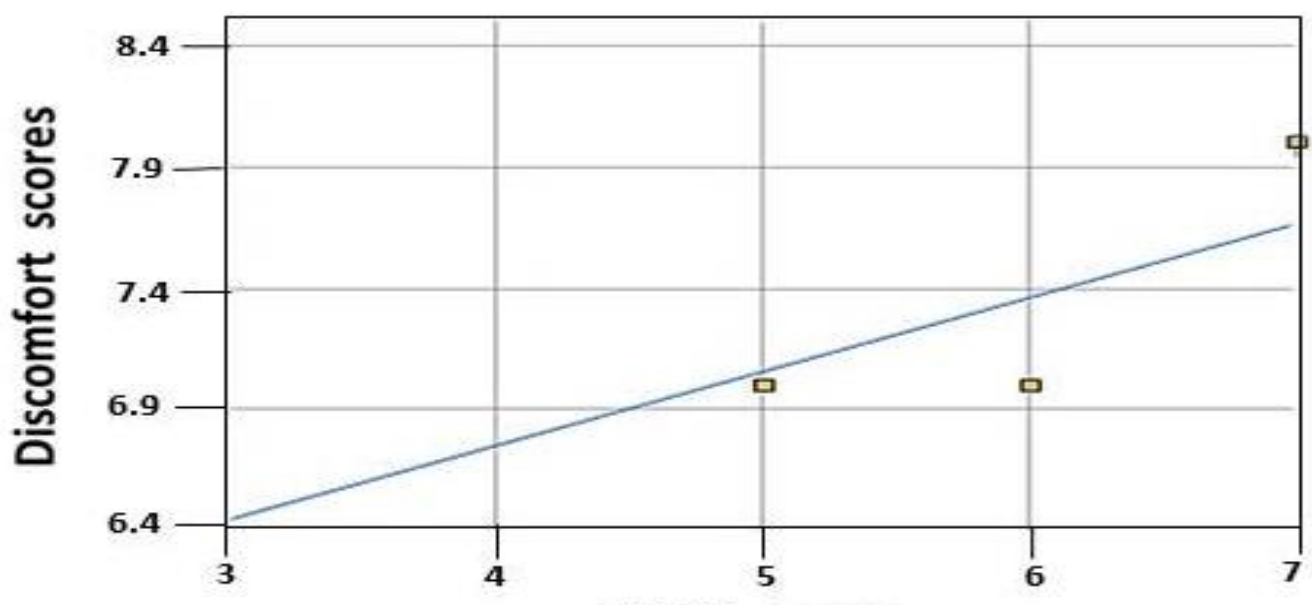

RULA scores

Regression line - $\hat{y}=0.30455 x+5.53636$

Fig 3. Linear regression between discomfort level and risk level at upper limbs in different working posture

\begin{tabular}{|c|c|c|}
\hline \multicolumn{3}{|c|}{ Table 7. Correlation between upper limbs and discomfort levels } \\
\hline Figures (from Table 3) & REBA score & Level of discomfort \\
\hline 1 & 7.0 & 8.0 \\
\hline 2 & 5.0 & 7.0 \\
\hline 3 & 5.0 & 7.0 \\
\hline 4 & 6.0 & 7.0 \\
\hline 5 & 3.0 & 6.5 \\
\hline 6 & 5.0 & 7.0 \\
\hline $\begin{array}{l}\text { Pearson's correlation } \\
\text { coefficient (r) }\end{array}$ & 0.892 (strong positive correlation) \\
\hline$p$-value & \multicolumn{2}{c}{0.016} \\
\hline \multicolumn{2}{|c|}{} \\
\hline
\end{tabular}

The average value of the indoor WBGT index of the worksite was $31.9^{\circ} \mathrm{C}$, with a relative humidity of $59 \%$.

\section{Discussion}

Work-related musculoskeletal disorders are rapidly increasing among workers working in both large-scale industries as well as in small scale cottage industries in India ${ }^{25}$. Various socioeconomic conditions like poverty associated with malnutrition, unscientific working posture, adverse working conditions, excessive working hours, etc aggravate the situation ${ }^{26}$. In our present study, maximum work-related musculoskeletal disorders were found maximally up to $71.73 \%$ of fireworks workers (age group 40-49years) predominantly involving the lower back. However, pain and stiffness were also reported in the upper back, neck, wrist, elbow, knee and ankle. In this 
present investigation increased prevalence of work-related musculoskeletal disorders were also reported with the advancement of age. Shyam and Dutt (2017) reported significant relation between age, years and working hours as well as marital status with the development of workrelated musculoskeletal disorders which affect almost $70 \%$ of the working group involved in textile industries of Meerat ${ }^{27}$. Prevalence of work-related musculoskeletal disorders with $58.8 \%$ of coir industry workers was also reported in Kerala ${ }^{28}$. Very recently, work related musculoskeletal disorders were also reported among manufacturing workers ${ }^{29}$.

\section{Conclusion}

After analysis of ergonomic factors and results, it can be concluded that the fire workers who are working with awkward postures have a high risk of developing WMSDs especially affecting the upper limbs and both upper and lower back. Unfavorable working environment, unscientific working postures with psychosocial factors and age significantly caused the development of local and multisite symptoms. Provisions of backrest with support is strongly recommended to reduce postural strains in the lumbar region which is most adversely affected.

\section{Conflict of interest}

The authors declare that there is no conflict of interest regarding the publication of this article.

\section{Ethical statement}

The workers who participated in the study were thoroughly informed about the aim and purpose of the study and their consents were taken. Data were collected following the guidelines of the Institutional Ethical Committee (Human) and the Declaration of Helsinki.

\section{Acknowledgement}

The authors would like to acknowledge and thank the fire workers of Champahati who kindly participated in this research along with all others who provided their help in any form.

\section{References}

1. Cao X, Daniel QT, Xuelei Z and Chen W. Review on physicochemical properties of pollutants released from fireworks: Environmental and health effects and prevention. Environmental Reviews, 2017,26(2):

https://doi.org/10.1139/er-2017-0063

2.Turner JA, Franklin G, Fulton-Kehoe D, Egan K, Wickizer TM, Lymp JF, Sheppard L and Kaufman JD. Prediction of chronic disability in work related musculoskeletal disorders: a perspective, population based study.BMC Musculoskeletal Disorders, 2004, 5:14 : PMID15157280. https://doi.org/10.1186/1471-2474-5-14

3. Hartvigsen J. Musculoskeletal disorders and disability. Pain, 2013, 154(10): 1904-1905.

https://doi.org/10.1016/j.pain.2013.06.036 
4. Cao X, Daniel QT, Xuelei and Chen W. Review on physicochemical properties of pollutants released from fireworks: Environmental and health effects and prevention. Environmental Reviews,2017, 26(2): https://doi.org/10.1139/er-2017-0063

5.Freire ACGF, Soares GB, Rovida TAS, Gabin CAS, Garbin AJI. Musculoskeletal disorders and disability in Brazilian dentists in Sao Paulo. Rev.dor Sao Paulo, 2017,18(2): 97-102.

https://doi.org/10.5935/1806-0013.20170020

6. Hossain MD, Aftab A, AlImam MH, Mohmad I, Choudhury IA, Kabir RI, Sarkar M. Prevalence of work related musculoskeletal disorders (WMSDs) and ergonomic risk assessment among readymade garment workers of Bangladesh: A cross sectional study. PLoS ONE, 2018, 13(7): e0200122.

https://doi.org/10.1371/journal.pone.0200122

7. Vandergift JL, Hanlon A, Gold J and Punnett L. Physical and psychosocial ergonomic risk factors for low back pain in automobile manufacturing workers. Occupational and Environmental Medicine, 2010, 69(1): 29-34. https://doi.org/10.1136/oem.2010.061770

8. Comper MLC and Padula RS. Ergonomic risk assessment among textile industry workers using two instruments: Quick exposure and Job factors questionnaire. Fisioter pes, 2013, 20(3): 215-221

9. Lucas RAI, Epistein Y and Kjellstrom T. Excessive occupational heat exposure : a significant ergonomic challenge and health risk for current and future workers. Extrem. Physiol. Med., 2014, 3(14) PMID: 25057350 https://doi.org/10.1186/2046-7648-3-14

10. Golchha V, Sharma P, Wadhwa J, Yadav D and Paul R. Exgonomic risk factors and their association with musculoskeletal disorders among Indian dentist: A preliminary study using Rapid upper limb Assessment. Indian Journal of Dental Research, 2014, 25(6): 767-771

11. Charles LE, Ma CC, Burchfiel CM and Dong RG. Vibration and Ergonomic exposure associated with musculoskeletal disorders of shoulder and Neck. Saf. Health Work,2018, 9(2):125-135

12. Noor U, Otman N, Abdullah UNN and Awang A. Ergonomic risk analysis and mental work load study among operator in syringe assemblylines. Human Factors Journal, 2017, 2(3):7-11

13. Kim JY, Shin JS, Lim MS, Choi HG, Kim SK, Kang HT, Koh SB and Oh SS. Relationship between simultaneous exposure to ergonomic risk factors and work-related lower back pain : a cross sectional study based on the forth Korean working conditions survey. Ann. Occup. Environ. Med., 2018, 30(58): PMID30202535 https://doi.org/10.1186/s40557-018-0269-1

14. Mohan SB. Identifying and controlling Ergonomic risk factors in construction. Ergonomics, 2018, 8(4): https://doi.org/10.4172/2165-7556.1000235

15. Saedpanah K, Motamedzade M, Salimi K, Eskandari T and Samaei SE. Physical risk factors among construction workers by work place ergonomic risk assessment (WERA) method. Archives of occupational health, 2(1):56-62

16. Buckle P. Ergonomics and musculoskeletal disorders: overview. Occupational Medicine. 2005; 55:164-167. https://doi.org/10.1093/occmed/kqi081 PMID: 15857895

17) 1) Kuorinka I, Johnson B, Kilbom A, Vinterberg H, Biering-Sørenson F, Andersson G, et al. Standardised Nordic questionnaires for the analysis of musculoskeletal symptoms. Appl Ergon. 1987 Sep;18(3):233-7.

18)Cole TJ, Bellizzi MC, Flegal KM, Dietz WH. Establishing a standard definition for child overweight and obesity worldwide: international survey. BMJ. 2000;320:1-6. 
19) Dickinson CE, Campion K, Foster AF, Newman SJ, O’Rourke AMT, Thomas PG. Questionnaire development: an examination of the Nordic musculoskeletal questionnaire. Appl Ergon. 1992;23(3):197-201.

20) Yaglou CP, Minard D. Control of heat casualties at military training centers. AMA Arch Ind Health. 1957;16(4):302-16.

21) Tayyari F, Smith JL. Occupational ergonomics. London, UK: Chapman \& Hall; 1997.

22) Hignett S, McAtamney L. Rapid entire body assessment (REBA). Appl Ergon. 2000 Apr;31(2):201-5.

23) M. Yusuf a Nyoman Adiputra b I Dewa Putu Sutjana c Ketut Tirtayasa . The Improvement of Work Posture Using RULA (Rapid Upper Limb Assessment) Analysis to Decrease Subjective Disorders of Strawberry Farmers in Bali . International Research Journal of Engineering, IT \& Scientific Research (IRJEIS). Vol. 2 Issue 9, September 2016, pp. 1 6

24) Somnath Gangopadhyay, Tirthankar Ghosh, Tamal Das, Goutam Ghoshal, Banibrata Das. effect of working posture on occurrence of musculoskeletal disorders among the sand core making workers of west bengal. Cent Eur $\mathbf{J}$ Public Health 2010; 18 (1): 38-42

25) Srivastav AK, Bihari V. Occupational health for woman-A current need.JSci Indian Res.2000; 59:995-1001.

26) P. Parimalam, N. Kamalamma, A.K. Ganguli. Ergonomic intervention to improve work environment in garment manufacturing units. IntJoccupenvi med.August 2006; 10 (2):20 -27.

27) Shyam, S. and Dutt, R. (2017). Determinants of Musculoskeletal Disorders among Small-Scale Textile Workers: A Cross Sectional Study. National Journal of Community Medicine, 8(10), 611-615.

28) M. Satheeshkumar and K. Krishnakumar, 2018. Study on Work-Related Musculoskeletal Disorders among Coir Industry Workers in the State of Kerala, India. In book: Ergonomic Design of Products and Worksystems - 21st Century Perspectives of Asia, pp.117-130

29) S Bao, N Howard and Jia-Hua Lin, 2020. Are Work-Related Musculoskeletal Disorders Claims Related to Risk Factors in Workplaces of the Manufacturing Industry? Ann Work Expo Health, 20;64(2):152-164 